\title{
Gambaran Klinis Glomerulonefritis Akut pada Anak di Departemen Ilmu Kesehatan Anak Rumah Sakit Cipto Mangunkusumo, Jakarta
}

\author{
Sudung O. Pardede, Partini P. Trihono, Taralan Tambunan
}

\begin{abstract}
Glomerulonefritis akut merupakan glomerulonefritis yang sering ditemukan pada anak ditandai dengan hematuria, hipertensi, edem, dan penurunan fungsi ginjal. Glomerulonefritis akut pada anak paling sering ditemukan pada umur 2-10 tahun dan umumnya terjadi pasca infeksi streptokokus.

Tujuan: mengetahui gambaran klinis glomerulonefritis akut pada anak di Departemen Ilmu Kesehatan Anak RSCM, Jakarta.

Metoda: penelitian deskriptif retrospektif. Data diperoleh dari catatan medik pasien dengan diagnosis glomerulonefritis akut yang berobat di Departemen Ilmu Kesehatan Anak RSCM, Jakarta, sejak tahun 1998 sampai 2002.

Hasil: selama 5 tahun (1998-2002), didapatkan 45 pasien glomerulonefritis akut (26 laki-laki dan 19 perempuan) yang berumur antara $4-14$ tahun dengan umur paling sering adalah 6-11 tahun. Riwayat infeksi saluran nafas akut didapatkan pada 36 pasien, dan infeksi kulit 14 pasien. Hematuria makroskopik didapatkan pada 29 pasien, anuria/ oliguria 31 pasien, dan edem pada 39 pasien. Hipertensi dijumpai pada 39 pasien, 19 di antaranya merupakan hipertensi krisis. Proteinuria dan hematuria mikroskopik didapatkan pada semua pasien, leukosituria 29 pasien. Penurunan fungsi ginjal didapatkan pada 21 pasien, peningkatan titer ASO 21 pasien, dan komplemen $\mathrm{C}_{3}$ yang menurun 32 pasien.

Kesimpulan: hematuria, proteinuria, edem, hipertensi, dan oligo/anuria merupakan manifestasi klinis glomerulonefritis akut yang paling sering ditemukan pada anak. Dibandingkan dengan periode sebelumnya, kejadian glomerulonefritis akut semakin menurun.
\end{abstract}

Kata kunci: glomerulonefritis akut, hematuria, hipertensi, proteinuria, oligo/anuria

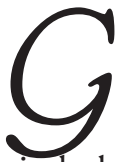
lomerulonefritis akut (GNA) merupakan penyakit yang sering ditemukan pada anak. Penyakit ini ditandai dengan hematuria yang timbul mendadak, hipertensi, edem, dan penurunan fungsi ginjal. Meskipun penyakit ini dapat mengenai

Alamat Korespondensi:

Dr. Sudung O. Pardede, Sp.A.(K)

Divisi Nefrologi. Departemen Ilmu Kesehatan Anak FKUI-RSCM.

Jl. Salemba no. 6, Jakarta 10430.

Telepon: 021-3915179. Fax.021-390 7743. semua umur, tetapi GNA paling sering didapatkan pada anak berumur 2-10 tahun. Angka kejadian GNA sulit diketahui dan diperkirakan lebih tinggi dari angka kejadian yang dilaporkan dalam kepustakaan sebab banyak pasien yang tidak terdeteksi karena gejalanya ringan atau tidak menunjukkan gejala., ${ }^{1,2,3}$

Penyebab GNA adalah bakteri, virus, dan proses imunologis lainnya, tetapi pada anak penyebab paling sering adalah pasca infeksi streptococcus $\beta$ haemolyticus; sehingga seringkali di dalam pembicaraan GNA pada anak yang dimaksud adalah GNA pasca streptokokus. 
Dengan membaiknya derajat kesehatan masyarakat, kejadian penyakit infeksi semakin menurun dan kejadian GNA terutama pasca streptokokus juga semakin menurun. ${ }^{1,2,3}$

Manifestasi klinis GNA sangat bervariasi, mulai dari yang ringan atau tanpa gejala sampai yang berat. Gejala pertama yang paling sering ditemukan adalah edem palpebra. Hematuria berat sering menyebabkan orangtua membawa anaknya berobat ke dokter. Pada pemeriksaan fisis, selain edem, hipertensi merupakan tanda klinis yang sering ditemukan. Manifestasi klinis yang berat dapat juga ditemukan jika terjadi komplikasi seperti gagal ginjal, gagal jantung, atau hipertensi ensefalopati. ${ }^{3,4}$

Tujuan penelitian ini adalah untuk mengetahui gambaran klinis GNA pada anak di Departemen Ilmu Kesehatan Anak FKUI RSCM, Jakarta dibandingkan dengan kejadian lima tahun sebelumnya.

\section{Bahan dan cara}

Penelitian ini merupakan penelitian deskriptif retrospektif. Data diambil dari catatan medik pasien GNA yang berobat di Departemen Ilmu Kesehatan Anak FKUI RSCM, Jakarta sejak tahun 1998 sampai dengan 2002. Data yang dikumpulkan meliputi umur, jenis kelamin, manifestasi klinis, dan laboratorium.

Hipertensi pada anak didefinisikan berdasarkan Task Force on Blood Pressure Control in Children yaitu jika tekanan darah >persentil 95 berdasarkan umur dan jenis kelamin dengan pemeriksaan 3 kali berturutturut. ${ }^{5}$ Hipertensi krisis didefinisikan sebagai tekanan darah sistolik $\geq 180 \mathrm{mmHg}$ dan atau diastolik $\geq 120$ $\mathrm{mmHg}$ atau setiap tingkat hipertensi yang disertai komplikasi ensefalopati hipertensi, gagal jantung, dan edem papil. Pada bayi dan anak berumur $<5$ tahun digunakan definisi hipertensi krisis jika tekanan darah meningkat 50\% dari nilai tekanan darah normal atau $>1 \frac{1}{2}$ kali batas atas tekanan darah normal berdasarkan umur dan jenis kelamin. ${ }^{6}$

Hematuria didefinisikan apabila jumlah eritrosit dalam urin $>5 /$ lapang pandang besar (LPB) dan leukosituria jika jumlah leukosit urin $>5 / \mathrm{LPB}^{7}$ Proteinuria diartikan dengan hasil urinalisis menunjukkan proteinuria $\geq 1+{ }^{8}$ Oliguria didefinisikan sebagai jumlah urin $<1 \mathrm{ml} / \mathrm{kgbb} /$ jam pada bayi dan $<0,8 \mathrm{ml} /$ $\mathrm{kgbb} /$ jam pada anak. ${ }^{9}$

\section{Hasil}

Selama 5 tahun (1998-2002), didapatkan 45 pasien GNA $(0,4 \%)$ yaitu di antara 10.709 pasien yang berobat di Departemen Ilmu Kesehatan Anak RSCM pada saat yang sama atau 9 kasus per tahun. Keempatpuluh lima pasien ini terdiri dari 26 laki-laki dan 19 perempuan $(1,4: 1)$ yang berumur antara $4-$ 14 tahun, dan umur yang paling sering adalah 6-11 tahun. (Tabel 1)

Tabel 1. Distribusi glomerulonefritis akut menurut umur dan jenis kelamin

\begin{tabular}{cccc}
\hline Umur ( tahun) & Laki-laki & Perempuan & Jumlah \\
\hline$<4$ & 0 & 0 & 0 \\
$4-5$ & 2 & 5 & 7 \\
$6-7$ & 8 & 4 & 12 \\
$8-9$ & 4 & 5 & 9 \\
$10-11$ & 5 & 4 & 9 \\
$12-13$ & 6 & 1 & 7 \\
$>13$ & 1 & 0 & 1 \\
\hline Jumlah \% & $26(58)$ & $19(42)$ & 45 \\
\hline
\end{tabular}

Riwayat infeksi saluran nafas akut didapatkan pada 36/45 pasien dan infeksi kulit pada 14/45 pasien. Edem, hipertensi, dan oliguria/auria merupakan gejala klinis yang paling sering ditemukan,(Tabel 2). Hematuria makroskopik 29/45 pasien, anuria/oliguria pada 31/45 pasien, dan edem pada 39/45 pasien. Hipertensi di derita oleh 39/45 pasien dan di antaranya merupakan hipertensi krisis. Proteinuria dan hematuria mikroskopik merupakan gambaran laboratorium yang paling sering ditemukan dan didapatkan pada semua pasien. Kelainan laboratorium lain yang sering ditemukan adalah peningkatan titer ASO (antistreptolisin O) pada 21/

Tabel 2. Manifestasi klinis glomerulonefritis akut

\begin{tabular}{lcc}
\hline Manifestasi klinis & Jumlah pasien & $\%$ \\
\hline Riwayat infeksi saluran nafas akut & 36 & 80,0 \\
Riwayat infeksi kulit & 14 & 31,1 \\
Anuria/oliguria & 31 & 68,9 \\
Hematuria makroskopik & 29 & 64,4 \\
Edem & 39 & 86,7 \\
Hipertensi & 39 & 86,7 \\
$\quad$ - hipertensi krisis & 19 & 48,7 \\
- hipertensi non krisis & 20 & 51,3 \\
\hline
\end{tabular}


31 pasien dan komplemen $\mathrm{C}_{3}$ yang menurun pada 32/ 34 pasien, dan tidak ada data mengenai titer ASO dan komplemen $\mathrm{C}_{3}$ pada masing-masing 14 dan 11 pasien. Leukosituria 29/45 dan anemia pada 25/45 pasien. Laju filtrasi glomerulus (LFG) menurun didapatkan pada 21/ 45, hipoalbuminemia ringan 18/45, dan leukositosis 20/45 pasien. (Tabel 3)

Tabel 3. Gambaran laboratorium glomerulonefritis akut

\begin{tabular}{lcc}
\hline Hasil laboratoium & Jumlah pasien & $\%$ \\
\hline Proteinuria & 45 & 100 \\
Hematuria & 45 & 100 \\
Komplemen C menurun $(\mathrm{n}=34)$ & 32 & 94,1 \\
Peningkatan titer ASO $(\mathrm{n}=31)$ & 21 & 67,7 \\
Leukosituria & 29 & 64,4 \\
Anemia & 25 & 55,6 \\
Penurunan LFG* & 21 & 46,6 \\
Leukositosis & 20 & 44,4 \\
Hipoalbuminemia & 18 & 40,0 \\
\hline
\end{tabular}

* LFG = laju filtrasi glomerulus

\section{Diskusi}

Selama 5 tahun (1998-2002), didapatkan 45 pasien GNA $(0,4 \%)$ di antara 10.709 pasien yang berobat pada saat yang sama di Departemen Ilmu Kesehatan Anak FKUI RSCM, Jakarta atau 9 kasus baru per tahun. Kejadian yang hampir sama juga dilaporkan Al Mosai (2002) yaitu 47 GNA selama 5 tahun di rumah sakit Bagdad atau 9-10 kasus per tahun. ${ }^{10}$

Angka kejadian pada penelitian ini lebih rendah dibandingkan dengan laporan sebelumnya. Pada tahun 1983, Alatas dkk. melaporkan 118 kasus GNA selama 5 tahun atau 24 kasus per tahun, ${ }^{11}$ dan pada tahun 1996 Alatas dkk melaporkan 140 pasien GNA $1,25 \%$ di antara 11.162 pasien yang dirawat di Departemen Ilmu Kesehatan Anak RSCM, Jakarta selama 5 tahun (1991-1995) atau 28 pasien per tahun. ${ }^{12}$ Penurunan kejadian ini kemungkinan disebabkan oleh menurunnya kejadian GNA karena kejadian infeksi yang semakin menurun akibat membaiknya tingkat kesehatan penduduk, atau kasus GNA tidak semuanya dirujuk ke RSCM karena meningkatnya kemampuan rumah sakit di luar RSCM, atau karena sebab lain.

Pada penelitian ini, pasien berumur antara $4-$ 14 tahun dengan umur paling sering adalah 6-11 tahun. Kejadian ini hampir sama dengan yang ditemukan penelitian sebelumnya. Sardjito dkk.,
(1989) melaporkan 170 kasus berumur antara 2 tahun - 15 tahun dengan umur terbanyak $6-12$ tahun. ${ }^{13}$ Albar dan Rauf (2002) melaporkan 276 pasien GNA selama 5 tahun di delapan rumah sakit pendidikan di Indonesia, berumur $21 / 2-14 \frac{1}{2}$ tahun dengan umur terbanyak $>6$ tahun $(77,1 \%) .{ }^{14} \mathrm{Al}$ Mosai (2002) dan Kasahara dkk., (2001) melaporkan pasien GNA berumur 3 - 14 tahun. $^{10,15}$ Kasahara dkk., (2001), ${ }^{15}$ dan Alatas dkk. (1983) ${ }^{11}$ melaporkan sebagian besar pasien GNA berumur 6 1/2 - 7 tahun. Pada penelitian ini, $12 / 45$ pasien berumur $6-7$ tahun dan tidak ada yang berumur $<4$ tahun, sedangkan Alatas dkk. (1983) melaporkan 4/118 pasien berumur $<3$ tahun. ${ }^{11}$

Kejadian GNA lebih sering ditemukan pada lakilaki daripada perempuan dengan perbandingan $2: 1 .^{3}$ Pada penelitian ini laki-laki lebih sering daripada perempuan $(1,4: 1)$ dan tidak berbeda dengan penelitian lain. Alatas dkk.(1983) melaporkan perbandingan laki-laki : perempuan : 1,7: $1,{ }^{11} \mathrm{Al}$ Mosai (2002) melaporkan 2,3 : 1, ${ }^{10}$ Kasahara dkk., (2001) melaporkan 60,9\% : 39,1\% (1,6 : 1), ${ }^{15}$ Sardjito dkk., (1989) melaporkan 1,3:1, ${ }^{13}$ dan Albar dan Rauf (2002) melaporkan 50,4\%: 49,6\% atau 1,04: $1 .{ }^{14}$

Riwayat infeksi saluran nafas akut didapatkan pada $80 \%$. Hasil ini lebih tinggi dari laporan sebelumnya di rumah sakit yang sama oleh Alatas dkk. (1983) yaitu $61,8 \% .{ }^{11}$ Peneliti lain melaporkan angka yang bervariasi. Albar dan Rauf (2002) melaporkan $49,1 \%,{ }^{14}$ Sardjito dkk., (1989) melaporkan $44 \%,{ }^{13}$ sedangkan Al Mosai (2002) melaporkan riwayat infeksi saluran nafas akut didapatkan pada 100\% kasus GNA anak di Irak. ${ }^{10}$

Riwayat infeksi kulit didapatkan pada 31\%. Angka yang hampir sama dilaporkan oleh Sardjito dkk., (1989) yaitu 38\% kasus, ${ }^{13}$ sedangkan penelitian lain melaporkan angka yang lebih rendah seperti Alatas dkk., (1983) melaporkan 16,9\%, ${ }^{11}$ Albar dan Rauf (2002) melaporkan 19,8\%; ; ${ }^{14}$ an Al Mosai (2002) melaporkan tidak ada riwayat infeksi kulit pada kasusnya. ${ }^{10}$

Anuria/oliguria didapatkan pada 69\%. Hasil ini lebih tinggi dari penelitian lain. Alatas dkk., (1983) melaporkan 43,2\%, ${ }^{11}$ Sardjito dkk., (1989) melaporkan 43\%, ${ }^{13}$ Albar dan Rauf (2002) melaporkan 24,2\%, ${ }^{14}$ tetapi Al Mosai (2002) melaporkan 100\%. ${ }^{10}$ Perbedaan ini kemungkinan berkaitan dengan berat ringannya manifestasi penyakit pada saat berobat ke rumah sakit. 
Hematuria makroskopis yang tidak disertai rasa nyeri merupakan gejala yang sering ditemukan. ${ }^{3}$ Pada penelitian ini, hematuria makroskopik didapatkan pada 64\%. Albar dan Rauf (2002) melaporkan 59,5\%; ${ }^{14}$ Sardjito dkk., (1989) melaporkan 55\%, ${ }^{13}$ Alatas dkk., (1983) melaporkan 40,6 \%. ${ }^{14}$

Edem merupakan manifestasi klinis yang sering ditemukan yaitu sekitar $85 \%$, dan kadang-kadang disertai edem paru (14\%) atau gagal jantung kongestif $(2 \%) .{ }^{3}$ Pada penelitian ini edem didapatkan pada $87 \%$. Hasil ini hampir sama dengan penelitian sebelumnya. Alatas dkk., (1983) melaporkan 85,5 \%, ${ }^{11}$ Sardjito dkk., (1989) masingmasing 87\%, ${ }^{13}$ Kasahara dkk., (2001) masingmasing 85,5\%; ; $^{15}$ Al Mosai (2002) masing-masing $87,0 \%,{ }^{10}$ dan Albar dan Rauf (2002) melaporkan masing-masing $82,5 \% .^{14}$

Hipertensi merupakan gejala yang sering didapatkan GNA yaitu $60-80 \%$ pasien. ${ }^{3}$ Pada penelitian ini hipertensi didapatkan pada $87 \%$, dan tidak berbeda dengan penelitian lainnya. Alatas dkk., (1983) masingmasing 86,4\%, ${ }^{11}$ Sardjito dkk., (1989) masing-masing $68 \%,{ }^{13}$ Kasahara dkk., (2001) masing-masing 64,5\%; ${ }^{15}$ Al Mosai (2002) masing-masing 87,0\%, ${ }^{10}$ dan Albar dan Rauf (2002) masing-masing melaporkan 60,4\%. ${ }^{14}$ Hipertensi krisis atau hipertensi ensefalopati jarang dijumpai, ${ }^{3}$ tetapi pada penelitian ini hipertensi krisis didapatkan pada 48,7\%. Tingginya kejadian hipertensi krisis pada penelitian ini mungkin berhubungan dengan keterlambatan pasien dibawa ke fasilitas pelayanan kesehatan.

Pada urinalisis dapat ditemukan proteinuria, hematuria, eritrosit dismorfik, silinder eritrosit, leukosituria, silinder leukosit, silinder hialin dan granular, namun kadang-kadang dapat ditemukan urinalisis yang normal. Proteinuria biasanya bukan proteinuria nefrotik meskipun proteinuria nefrotik dapat ditemukan pada $<5 \%$ pasien. ${ }^{3}$ Pada penelitian ini, proteinuria didapatkan pada $100 \%$. Angka yang sama dilaporkan oleh Al Mosai (2002) yaitu 100,0\%, ${ }^{10}$ Kasahara dkk., (2001) 82,6\%; ${ }^{15}$ Sardjito dkk., (1989) 79,9\%, ${ }^{13}$ Alatas dkk., (1983) 73,7 \%, ${ }^{11}$ dan Albar dan Rauf (2002) melaporkan 65,7\%. ${ }^{14}$ Hematuria mikroskopis umumnya didapatkan pada semua pasien. ${ }^{3}$ Pada penelitian ini, hematuria mikroskopis didapatkan pada $100 \%$ dan tidak berbeda dengan penelitian lain. Al Mosai (2002) 100,0\%, ${ }^{10}$ Albar dan Rauf (2002) 91,5\%, ${ }^{14}$ dan Kasahara dkk., (2001) melaporkan $99,6 \% .{ }^{15}$
Sebagian besar GNA menunjukkan penurunan fungsi ginjal yang ditandai dengan peningkatan kreatinin dan ureum plasma atau penurunan laju filtrasi glomerulus. Penurunan fungsi ginjal bervariasi bergantung pada berat ringannya penyakit dengan angka kejadian sekitar 45\%. ${ }^{3}$ Pada penelitian ini, penurunan laju filtrasi glomerulus didapatkan pada $46 \%$, dan tidak berbeda jauh dengan laporan sebelumnya. Alatas dkk., (1983) melaporkan 50,0 \%, ${ }^{11}$ dan Al Mosai (2002) 50,0\%, ${ }^{10}$ sedangkan Albar dan Rauf (2002) melaporkan peningkatan ureum plasma pada $23,9 \%$ dan kreatinin plasma $34,4 \%,{ }^{14}$ dan Kasahara dkk., (2001) melaporkan peningkatan ureum pada $34,8 \%$ dan kreatinin pada $1,4 \% .{ }^{15}$

Biakan usap tenggorok yang positif terhadap streptococcus hemolyticus didapatkan pada $20 \%$ kasus. Deteksi infeksi streptokokus dapat dilakukan dengan pemeriksaan antibodi terhadap antigen streptokokus seperti antistreptolisin $\mathrm{O}$, streptokinase, hialuronidase, DNAase B, dan NADase. Pada pasca infeksi streptokokus pada saluran nafas akut didapatkan peningkatan ASO pada $80-90 \%$, sedangkan pasca infeksi kulit didapatkan peningkatan ASO pada 50\%. ${ }^{3}$ Pada penelitan ini tidak ada data mengenai hasil biakan usap tenggorokan. Peningkatan titer ASO didapatkan pada $68 \%$, dan hampir sama dengan penelitian lain. Alatas dkk., (1983) melaporkan 61,0 \%, ${ }^{11}$ Albar dan Rauf (2002) 64,9\%, ${ }^{14}$ Sardjito dkk., (1989) 55\%, ${ }^{13}$ sedangkan Kasahara dkk., (2001) melaporkan angka yang lebih tinggi yaitu $90,6 \% .^{15}$

Pemeriksaan komplemen $\mathrm{C}_{3}$ penting untuk menegakkan diagnosis dan umumnya $\mathrm{C}_{3}$ menurun pada fase akut. Penurunan komplemen $\mathrm{C}_{3}$ dijumpai pada $80-90 \%{ }^{3}$ hingga $100 \%$ kasus. ${ }^{15}$ Hasil yang hampir sama didapatkan juga pada penelitian ini yaitu komplemen $\mathrm{C}_{3}$ menurun pada $94,1 \%$, sedangkan Alatas dkk., (1983) melaporkan 88,4\%. ${ }^{11}$

Kelainan metabolik dapat ditemukan sebagai manifestasi penurunan fungsi ginjal seperti peningkatan kreatinin dan ureum plasma, hiperkalemia, hiperfosfatemia, dan asidosis. Kelainan hematologis dapat berupa anemia dan trombositopenia. Anemia dapat disebabkan hemodilusi dan hemolisis ringan akibat pemendekan umur eritrosit. Selain itu anemia dapat juga disebabkan penyebab lain seperti anemia defisiensi. Trombositopenia terjadi karena menurunnya mean survival time trombosit. ${ }^{3}$ Pada penelitan ini anemia didapatkan pada $56 \%$ dan tidak terdapat trombositopenia. Albar dan Rauf (2002) melaporkan anemia 
pada 57,2\%; ${ }^{14}$ sedangkan Alatas dkk. (1983) melaporkan $73,7 \% .{ }^{11}$ Penurunan kejadian anemia pada penelitian ini dibandingkan dengan laporan Alatas dkk. (1983) mungkin ada hubungannya dengan perbaikan derajat kesehatan masyarakat.

Hipoalbuminemia ringan sering didapatkan pada GNA karena efek dilusi akibat penambahan volume intravaskular. ${ }^{3}$ Pada penelitian ini, hipoalbuminemia ringan didapatkan pada 18 pasien (40\%). Leukosituria didapatkan pada 64\% sedangkan Alatas dkk. (1983) mendapatkan pada 39,8 \%. ${ }^{11}$ Penyebab tingginya leukosituria pada penelitian ini tidak jelas dan tidak ada data mengenai pemeriksaan lanjutan, misalnya biakan urin.

\section{Kesimpulan}

Hematuria, proteinuria, edem, hipertensi, dan oligo/ anuria merupakan manifestasi klinis yang paling sering ditemukan pada anak dengan GNA. Di Departemen IKA RSCM, kejadian GNA semakin menurun dibandingkan dengan laporan lima tahun sebelumnya.

\section{Daftar Pustaka}

1. Travis LB, Kalia A. Acute nephritic syndrome. Dalam: Postlethwaite J, penyunting, Clinical paediatric nephrology, edisi ke-2, Oxford, Butterwoth Heinemann,1994. h. 201-9.

2. Noer MS. Glomerulonefritis. Dalam: Alatas H, Tambunan T, Trihono PP, Pardede SO, penyunting. Buku ajar nefrologi anak, edisi ke-2, Jakarta, Balai Penerbit FKUI, 2002. h. 323-61.

3. Smith JM, Faizan MK, Eddy AA. The child with acute nephritic syndrome. Dalam: Webb NAJ, Postlethwaite RJ, penyunting. Clinical paediatric nephrology, edisi ketiga. Oxford, Oxford University Press, 2003. h. 367-79.

4. Brouhard BH, Travis LB. Acute postinfectious glomerulonephritis. Dalam: Edelmann CM, Bernstein J, Meadow SR, Spitzer A, Travis LB, penyunting. Pediatric kidney disease, edisi kedua. Boston, Little Brown, 1992. h. 1199-221.
5. Task Force of Blood Pressure Control in Children. Report of the Second Task Force of Blood Pressure Control in Children-1987. Pediatrics 1987;79:1-25.

6. Alatas H. Masalah dan penanggulangan hipertensi pada anak. Sari Pediatri 1994;2:88-94.

7. Rauf S. Hematuria. Dalam: Alatas H, Tambunan T, Trihono PP, penyunting. Buku ajar nefrologi anak, edisi ke-1. Jakarta, Balai Penerbit FKUI, 1993. h. 81-92.

8. Wila Wirya IGN. Proteinuria. Dalam: Alatas H, Tambunan T, Trihono PP, penyunting. Buku ajar nefrologi anak, edisi ke-1. Jakarta, Balai Penerbit FKUI, 1993, h. 93-108.

9. Trompeter RS, Barratt TM. Abnormalities of urine volume. Dalam: Barratt TM, Avner ED, Harmon WE, penyunting. Pediatric Nephrology, edisi ke-4. Baltimore, Lippincott Williams \& Wilkins, 1999. h. 318.

10. Al-Mosawi AJ. The pattern of acute glomerulonephritis in 47 Iraqi children. Pediatr Nephrol 2002;17:74-5.

11. Alatas H, Akib A, Hermanses S. Glomerulonefritis akut pasca streptokokus pada anak. Maj Kedok Indones 1983;10;253-60.

12. Alatas H, Pardede SO, Tambunan T, Wila Wirya IGN. Pola penyakit ginjal dan saluran kemih pada anak di Bagian Ilmu Kesehatan Anak FKUI-RSCM, Jakarta. Diajukan pada KONIKA X di Bukit-tinggi tanggal 1621 Juni 1996.

13. Sardjito RH, Alatas H, Singadipura B, Damanik MP, Rauf S, Kari I K, dkk. Glomerulonefritis akut pasca streptokokus pada anak. Studi kolaboratif multi senter. Naskah Lengkap Simposium Nasional IV Nefrologi Anak dan Peningkatan Berkala Ilmu Kesehatan Anak ke-6, Bidang Nefrologi, IDAI Jawa Tengah. Semarang 23-24 Juni 1989. h. 176-94.

14. Albar H, Rauf S. Acute glomerulonephritis in children in Indonesia. A preliminary report of a multicentre study. Abstract $12^{\text {th }}$ National Congress of Child Health and $11^{\text {th }}$ ASEAN Pediatric Federation Conference, Bali, June 30 - July 4, 2002.

15. Kasahara T, Hayakawa H, Okubo S, Okugawa T, Kabuki N, Tomizawa S, dkk. Prognosis of acute poststreptococcal glomerulonephritis (APSGN) is excellent in children, when adequately diagnosed. Pediatr Intern 2001; 3:364-7. 